Technical Paper

\title{
Molecular Weight Measuring Methods for Saturate Fraction Separated from Heavy Oil
}

\author{
Shinya SATO ${ }^{\dagger}$ \\ (Received September 11, 2017)
重質油から分画した飽和分の分子量測定法
佐藤 信也

\begin{abstract}
Number average molecular weight (Mn) of saturates (CL), which recovered from Cold Lake oil sand bitumen by column chromatography (JPI-5S-22-83), was estimated from a chromatogram obtained by gaschromatographic distillation (GCD, ASTM D 7169), and compared with Mn measured by cryoscopy and gel permeation chromatography (GPC).

When Mn is estimated from a chromatogram obtained by GCD, the following conditions should be satisfied. The first, a chromatogram returns to baseline, and the second, the correlation between boiling point and molecular weight was known prior to the estimation. The second condition is filled with good linear correlations between the boiling points and the logarithm of the formula weights for alkanes and alkylbenzenes, respectively. For CL, the first condition was regarded to be filled because the chromatogram returns very close to the baseline. The Mn was estimated to be 400 using a calibration curve based on alkylbenzenes, because its $\mathrm{H} / \mathrm{C}$ atomic ratio (1.78) was closer to alkylbenzenes than to alkanes.

Cryoscopy is a more basic method for Mn measurement, because no calibrations are required. Here, the Mn was measured by cryoscopy using about $10 \mathrm{~mL}$ of p-Xylene solution with the concentrations of 17.2, 8.63, and $1.57 \mathrm{~g} / \mathrm{kg}$. As a result, Mn was calculated to be 370 .

In addition, a conventional gel permeation chromatography (GPC) method was performed, and the Mn was estimated to be 490 .

Comparing those three methods, GCD method is the most convenient when a sample meets the conditions described above. However, only saturate fraction can be applicable at a moment. Cryoscopy is applicable for any fractions in principle, but it requires relatively large sample amount (c.a. $150 \mathrm{mg}$ ), and it is available for a sample with Mn up to about 500. Mn obtained by GPC using polystyrene standards was most inaccurate among the methods described here. It is necessary to adopt new standards other than polystyrene for more reliable molecular weight measurement.
\end{abstract}

Cold Lake 産オイルサンドビチューメンよりカラムクロマトグラフィー法 (JPI-5S-22-83) で分画した飽和分 (CL) の数平 均分子量 (Mn) を蒸留ガスクロマトグラフィー (GCD, ASTM D 7169 準拠), 凝固点降下法, ゲル浸透クロマトグラフィー （GPC）で比較した。

GCD 法で Mn を推算する場合には，GCD で得られたクロマトグラムがベースラインに戻っていること，抄よび沸点と分 子量の相関が事前に分っていることという条件が必要である。後者については，アルカンおよびアルキルベンゼンで式量の 対数と沸点の間に一次の相関があることが利用できる。CL の試料ではクロマトグラムの終点がほぼベースラインに戻ってい ることから，最初の条件も満足していると見なした。CL の H/C 原子比 (1.78) はアルカンよりもアルキルベンゼンの值に近 いことから，アルキルベンゼンの沸点一分子量の関係を用いて $\mathrm{Mn}=400$ と推算された。

凝固点降下は較正曲線を用いないので，より基本的な分子量測定法である。本報告では $17.2,8.63,1.57 \mathrm{~g} / \mathrm{kg}$ の濃度 の p- キシレン溶液, 約 $10 \mathrm{~mL}$ を用い, 凝固点降下による分子量測定を行った。その結果, CL の分子量は 370 と推算された。 さらに, 従来法であるゲル浸透クロマトグラフィーによる測定を行った結果，ポリスチレンを標準物質とした場合の分子量 は 490 と推算された。

これら３種類の測定法を比較すると，GCDによる方法は，現状では飽和分にしか適用できないが，最も簡便な方法であ る。凝固点降下法は原理的にどのフラクションにも適用できるが, 多量の試料が（約 $150 \mathrm{mg}$ ) 必要，概ね分子量約 500 以 下の試料にしか適用できないという制約がある。GPC 法による Mn はこれらの測定法の中で最も不正確であり, GPC 法で 信頼性の高い分析を行うためにはポリスチレンに代わる標準物質が必要である。

\section{Key Words}

Heavy oil, Saturate fraction, Molecular weight, Gel permeation chromatography,

Gas-chromatographic distillation, Cryoscopy

Research Institute of Energy Frontier

National Institute of Advanced Industrial Science and Technology

16-1, Onogawa, Tsukuba, Ibaraki, 305-8569, Japan

† Corresponding author: s-sato@aist.go.jp
特定国立研究開発法人産業技術総合研究所

創エネルギー研究部門未利用炭素資源グループ

テ 305-8569＼cjkstart茨城県つ〈ば市小野川 16-1 


\section{1. 緒 論}

分子量は重質油の性状を示す重要な物性であり, 従来, 凝固点降下法, 蒸気圧浸透法 (VPO), ゲル浸透クロマトグ ラフィー（GPC） など様々な方法が適用されてきた。近年は 質量分析装置 (MS) を用いた測定 $\left.{ }^{1)} \sim 3\right)$ も頻繁に行われて いるが, 現在, 最も広く用いられるのは GPCであろう。 GPC は高速液体クロマトグラフィーのシステムに示差屈折 (RI) 検 出器や蒸発光散乱検出器 (ELSD) を繋いで測定され, 一 次データとして得られるのは保持時間とピーク強度である。 GPC カラムでは溶質が分子量の順に流出し, 分子量の対数 と保持時間の間に一次の相関がある。この相関を利用し, ポリスチレンを標準物質に用いて作成した保持時間一分子量 較正曲線を用いて保持時間を分子量に変換するのが一般的 な方法である。この方法では溶質は全てポリスチレンと同じ 較正曲線が適用できるとの仮定があることから，このように して得られた分子量は，ポリスチレン換算分子量と言われる。 多くの分子はポリスチレンとは分子形態や極性が異なるた め, その真の分子量とポリスチレン換算分子量は一致しない 場合が多い。この問題に対しては宾戸 ${ }^{4)}$, 張 5)らによる純物 質の GPCでのポリスチレン分子量と式量の相関を純物質の 分極率で補正した報告がある。これらは口頭のみの報告で, その詳細を知ることが困難であるため, 本稿の最後にその 概要を示す。

この報告で提案された相関は，H/C 原子比と分極率を必 要とするため, 未知試料への適用は難しい。そこで, 著者ら はアスファルテンの核と類似の分極率を示す純物質を標準物 質に選定し，これらの保持時間－分子量較正曲線を用いて ポリスチレン換算分子量を補正する方法 ${ }^{6)}$ ８)を提案している。 アスファルテンの較正曲線の補正に選定された物質はいずれ も円盤状の形態を持つ分極率の大きな物質であった。これ により従来は GPCクロマトグラムで分子量 100 以下の範囲 にも存在し, 過小評価されていたアスファルテンの分子量範 囲が 300 以上となり，その分子構造上，妥当な值となった。 他のフラクションでもこのような過大評価・過小評価が起き ていると考えられるが，それがどの程度であるかを推定する 方法は MS 以外には見当たらない。

重質油の沸点分布の測定に用いられる蒸留ガスクロマトグ ラフィー (GCD) は， ガスクロマトグラフの恒温槽を $450^{\circ} \mathrm{C}$ ま で昇温することにより， $\mathrm{C}_{100}$ までのワックス成分の分析が可 能である (ASTM D 7169)。この分析で得られるクロマトグ ラムは保持時間を標準物質で沸点に換算して得られ，GPC と類似の構造を持つ。もし沸点から分子量を推算できる場 合は，換算後に GPC と同様の計算で Mn を推算できるであ ろう。そこで, GCD から Mnの推定が可能であるかどうかを 検討した。但し GCD による方法も GPC 同様, 換算分子量 であるため, 凝固点降下法で換算によらない分子量を測定 し，GPC および GCD 法と比較し，その適用性を評価した ${ }^{9)}$ 。

\section{2. 実 験}

\section{1 試料および試薬}

試料は Cold Lake 産オイルサンドビチューメンの常圧残油 から石油学会法(JPI-5S-22-83) 準拠で分画した飽和分 (CL, $\mathrm{C}: 86.0 \mathrm{wt} \%, \mathrm{H}: 12.8 \mathrm{wt} \%, \mathrm{~S}: 1.12 \mathrm{wt} \%, \mathrm{H} / \mathrm{C}$ 原子比 = 1.78) を用いた ${ }^{10)}$ 。

テトラヒドロフラン (THF) および二硫化炭素 (CS2) は和 光純薬製 HPLC 用, p- キシレンは和光純薬製特級, アルキ ルベンゼンは東京化成製一級を用いた。

\section{2 装置および測定方法}

各分析装置の構成は以下の通りである。

1) GCD による分子量測定

GCD は以下の装置を用い, ASTM D 7169 に準拠して行っ た。

装置：Agilent 7890B GC システム, FID 検出器

カラム: Ultra Alloy - SIMDIS (HT), 内径 $0.53 \mathrm{~mm}$, 長 さ $5 \mathrm{~m}$, 膜圧 $0.1 \mu \mathrm{m}$ (Frontier Laboratories 社 製)

恒温槽: $50^{\circ} \mathrm{C} \sim 440^{\circ} \mathrm{C}, 10^{\circ} \mathrm{C} / \mathrm{min}$

注入口温度 : オーブントラックモード (恒温槽温度 $+3{ }^{\circ} \mathrm{C}$ で制御)

検出器温度 : $380^{\circ} \mathrm{C}$

試料: $1 \mathrm{wt} \%$ (二硫化炭素溶媒), 注入量 $1 \mu \mathrm{L}$

沸点較正用標準試料：ASTM D5442 $\mathrm{C}_{12}-\mathrm{C}_{60}$ 定量用試料

$\left(\mathrm{C}_{12}, \mathrm{C}_{14}, \mathrm{C}_{16}, \mathrm{C}_{18}, \mathrm{C}_{20}, \mathrm{C}_{22}, \mathrm{C}_{24}, \mathrm{C}_{26}, \mathrm{C}_{28}\right.$,

$\mathrm{C}_{30}, \mathrm{C}_{32}, \mathrm{C}_{36}, \mathrm{C}_{40}, \mathrm{C}_{44}, \mathrm{C}_{50}, \mathrm{C}_{60}$ のアルカン混合

物, Agilent 社製)

測定は, まず, 標準試料, ブランク, 次いで試料の順に行っ た。測定終了後, ブランクと試料のクロマトグラムをテキスト ファイルとして Excel に読み込み, ブランクのクロマトグラム を差し引いて解析用のクロマトグラムとした。このクロマトグ ラムについて標準試料で求めた保持時間－沸点較正曲線を 用いて保持時間を沸点に換算した。測定範囲での最大沸点 は常圧換算で約 $710^{\circ} \mathrm{C}$ であった。

次にアルカンとアルキルベンゼンについて沸点と式量の関 係を数式化し，その関係を用いて沸点を分子量に換算した。 CLの Mn は分子量をX 軸とするクロマトグラムより計算した。 2) 凝固点降下法

凝固点降下法は p- キシレンとCL で調製した $17.2 \mathrm{~g} / \mathrm{kg}$ の溶液 $10 \mathrm{~mL}$ を外径 $19 \mathrm{~mm}$ の受器に入れ, 最小表示桁が $1 / 1000^{\circ} \mathrm{C}$ のデジタル温度計（TL1-R12，ThermoPlobe 社製） を装着し， $5{ }^{\circ} \mathrm{C}$ に保温した水浴中で $200 \mathrm{rpm}$ で覺拌しなが ら測定した (Fig. 1)。温度変化はWeb カメラを用いて 10 秒 毎に温度表示を撮影し, 実験後に画像より温度と時間を読 み取った。次に, この試料を希釈して $8.63 \mathrm{~g} / \mathrm{kg}, 1.57 \mathrm{~g} /$ $\mathrm{kg}$ の試料を調製し, 同様の測定を行った。実験は各濃度で 4〜6回行い, 必要に応じ最大值, 最小值を省いて集計し, 凝固点変化の傾きと Kf から $\mathrm{Mn}$ を計算した。 


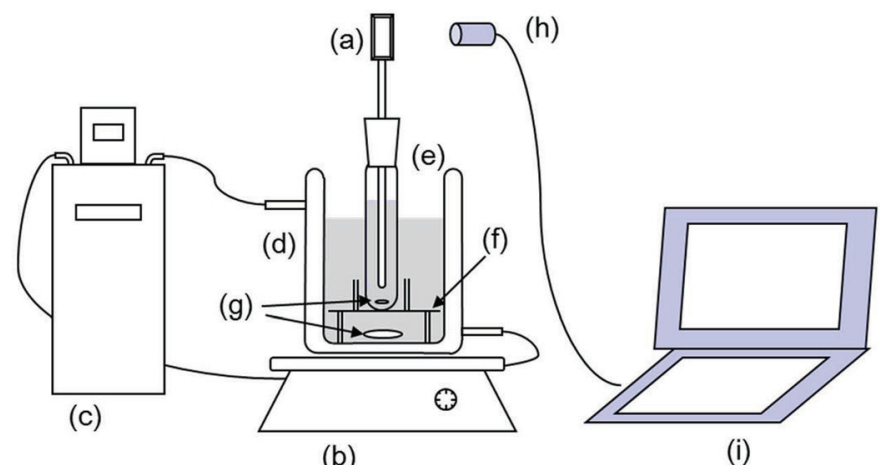

(b)

(a) Thermometer ( minimun display digit: $1 / 1000 \mathrm{~K}$ ), (b) Magnetic stirrer
(c) Low temperature circulator, (d) Beaker, jacket type, (e) Sample tube

(f) Spacer, (g) Stirring bar, (h) Web camera, (i) personal computer

Fig. 1 Schematic diagram of cryoscopic measurement appatus

3) GPC 分析

GPC 分析は以下の構成の装置で行った。

ポンプ: Agilent 1100 シリーズ

検出器: Agilent 1290 Infinity II ELSD 検出器

カラム：KF-403HQ 2 本 (粒径 $3 \mu \mathrm{m}$, カラム内径 4.6 $\mathrm{mm}$, 長さ $250 \mathrm{~mm}$, 排除限界 70,000, Shodex 社製)

移動相：テトラヒドロフラン ( $\mathrm{THF}), 0.25 \mathrm{~mL} / \mathrm{min}$

恒温槽 : $40^{\circ} \mathrm{C}$

注入量 : $20 \sim 40 \mu \mathrm{L}$

試料濃度：約 $600 \mathrm{ppm}$ (THF 溶媒)

検量線：ポリスチレン(分子量 49300, 9500, 2400, 500)

測定は GPC クロマトグラムをテキストファイルとして Excel に読み込んだ後，通常の GPC 解析法で Mn を計算した。

\section{3. 結果と考察}

\subsection{GCD による測定}

GCD は保持時間を沸点に変換することで沸点分布を測定 する方法であり，保持時間と沸点の換算にはアルカンを標準 物質として測定した保持時間と沸点の相関を用いる (Fig. 2)。 このクロマトグラムを用いて分子量を推算するためには，試 料が全量留出していること, および沸点を分子量に換算でき ることという2つの条件を満たす必要がある。

CLの GCD クロマトグラムの終点はベースラインよりもわず かに高いが, Fig. 3 (a) に示すクロマトグラムより留出してい ない量は無視できると判断した。このクロマトグラムを Fig. 2

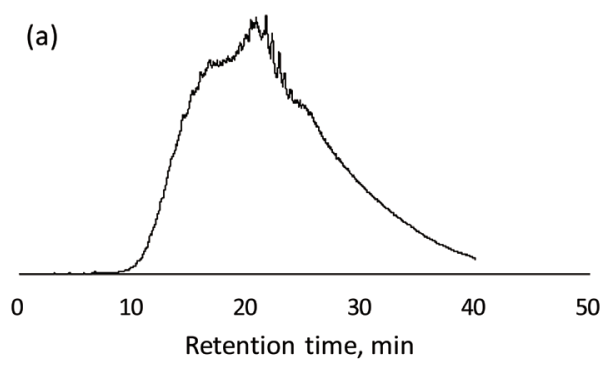

に示す較正曲線で沸点に換算した結果を Fig. 3 (b) に示す。 沸点を分子量に換算するためには，事前に較正曲線を求 めておく必要がある。本研究で用いた沸点較正用標準試料 の沸点 (BP) と分子量（式量 FW）の間には式 (1)の相関が ある (Fig. 4)。

$\log (\mathrm{FW})=0.0175 \cdot \mathrm{BP}+1.840$

さらに,アルキルベンゼン類では $\mathrm{C}_{7} \mathrm{H}_{8}$ (トルエン) 〜 $\mathrm{C}_{21} \mathrm{H}_{36}$ (ペンタデシルベンゼン, $\mathrm{bp}=373^{\circ} \mathrm{C}$ ) の間でアルカンと 同様，式 (2)の関係がある。

$\log (\mathrm{FW})=0.0181 \cdot \mathrm{BP}+1.792$

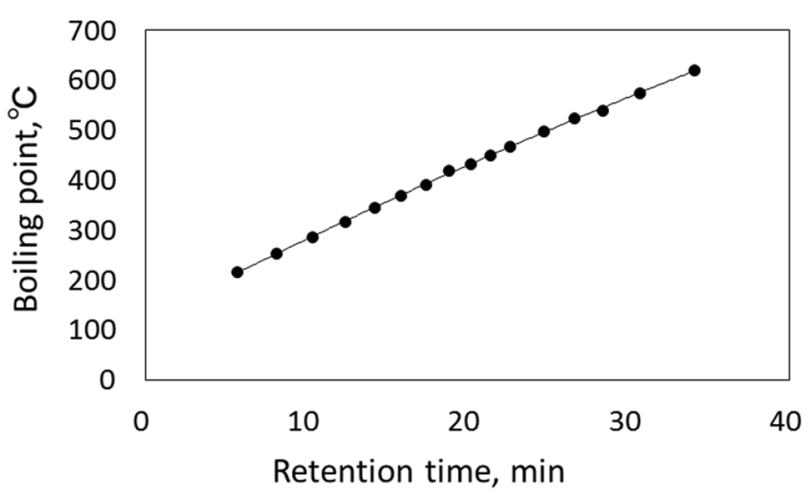

Correlation equation : $B P=-0.058 R T^{2}+16.54 R T+122.4$

Fig. 2 Correration between retention time (RT) and boiling points (BP) of alkanes

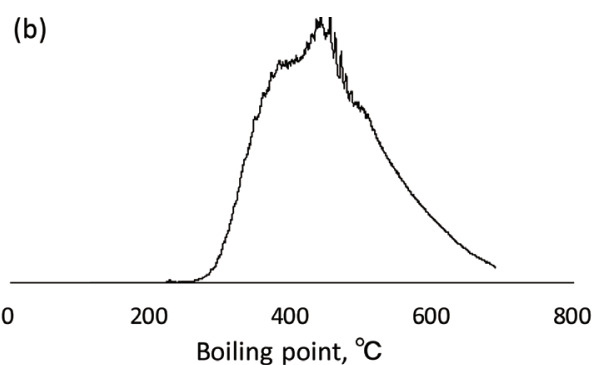

Fig. 3 GCD chromatogram of CL against retention time (a) and boiling point (b) 


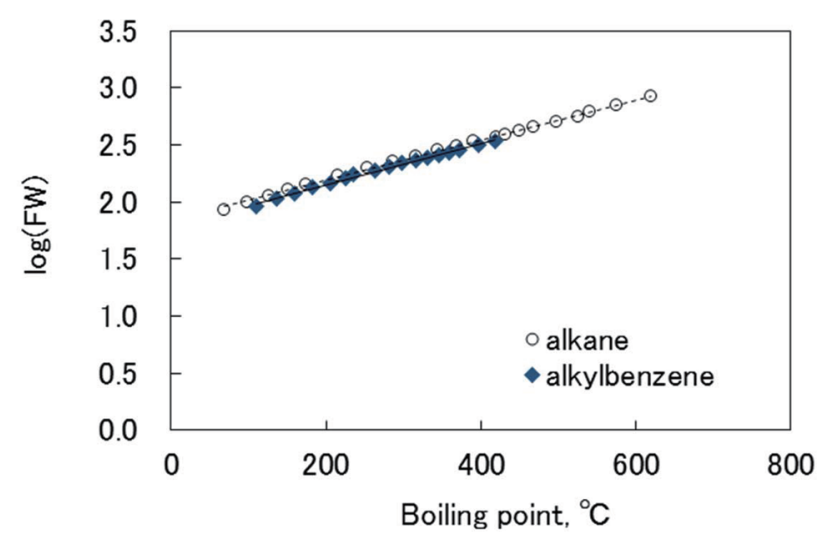

Correlation equation

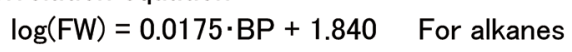

$\log (F W)=0.0181 \cdot B P+1.792 \quad$ For alkylbenzenes

Fig. 4 Correlations between boiling points (BP) and formula weight (FW) of alkanes and alkylbenzens

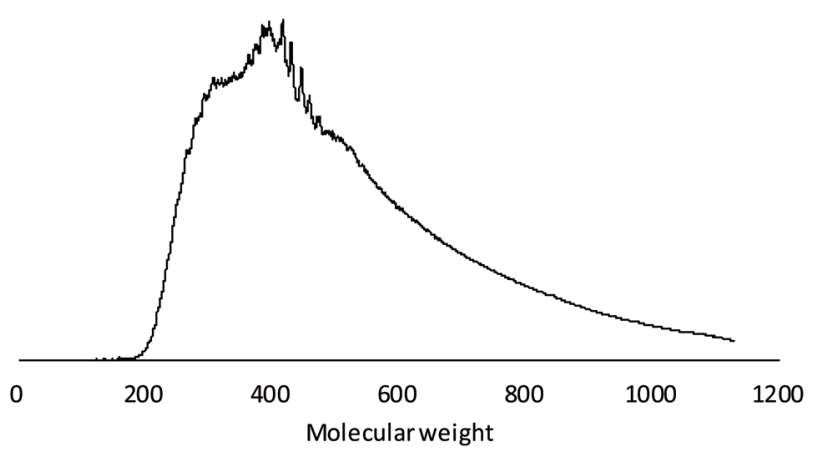

Fig. 5 Molecular distribution of CL determined by GCD

アルキルベンゼンの較正曲線がアルカンとほぼ一致してい ることから，アルキルベンゼンの較正曲線で $373^{\circ} \mathrm{C}$ 以上の領 域は, その外挿が使えると判断した。

CLでは，その H/C 原子比 (1.78) がアルカンよりはアル キルベンゼン類に近いことから, Fig. 3 (b) でクロマトグラム の沸点を式 (2)の較正曲線を用いて分子量に換算し, 分子 量分布のクロマトグラムを得た (Fig. 5)。次にこのクロマトグ ラムより GPCの場合と同様に計算した結果, $\mathrm{Mn}=400$ であっ た。

\section{2 凝固点降下法}

前節の GCD から Mn を求める方法は, 保持時間 - 沸点分子量と変換するために 2 種類の較正曲線を用いる。そのた め, この方法の妥当性を判断するためには実際の分子量を 知らなければならない。ちなみに, この事情は GPCでも同 様である。

そこで, 較正曲線を用いず, 物理化学的原理により分子 量を測定できる凝固点降下による測定を行った。物理化学 的原理による方法では蒸気圧浸透法 (VPO) による測定が 一般的であるが，VPO は専用装置が必要で一般に高価であ ることから, 近年はあまり行われていない。凝固点降下法も
比較的多量の試料が必要で, 操作に熟練を要すことから現 在はあまり行われていないのが実情であろう。そこで, 本実 験では比較的安価に入手できるパーツを組み合わせた装置 で測定可能な装置を組み立てた。この装置には $1 / 1000 \mathrm{~K}$ ま で表示可能なデジタル温度計を用い, 温度表示画面をWeb カメラで一定間隔で撮影することにより，温度読み取りにお ける熟練度の影響を排除した。解析はパーソナルコンピュー ターに保存された写真から温度を読み取り, グラフ化して冷 却曲線を作成して行った。

本測定の溶媒には p-キシレンを用いた。一般的に使用さ れるベンゼンは凝固点 $5.533^{\circ} \mathrm{C}$, モル凝固点降下係数 (Kf) = 5.12 であるが $\mathrm{p}$ - キシレンはそれぞれ, $13.263^{\circ} \mathrm{C}, 4.3$ で あり ${ }^{12)}$, ベンゼンの $85 \%$ の感度しかないが, 実験室での取 り扱いの制約は著しく軽減される。 曲線の再現精度の観点から凝固点降下量は $0.2^{\circ} \mathrm{C}$ 以上, 必 要な試料量の観点から試料濃度を $20 \mathrm{~g} / \mathrm{kg}$ 以下と設定した。 この条件では分子量の上限は約 500 となる。

Fig. 6 にCLの冷却曲線の例を示す。冷却曲線の再現性 は良いとはいえないので, 測定は各濃度に対し 5〜6回行い, 得られた凝固点の最大值, 最小值を省いた值を採用した。 3 種類の濃度で得られた凝固点降下量 (Fig. 7) より, 凝固 点降下は式 (3) で示された。

$$
\mathrm{T}=-0.0116 \cdot \mathrm{C}+13.228
$$

ここで C は溶液の濃度, $\mathrm{T}$ は $\mathrm{p}$ - キシレンの凝固点である。 式 (3)の傾きと p- キシレンのモル凝固点降下係数から計算 したCLの Mnは 370 であった。なお, Fig. 7 に示す測定点 を統計処理することで求められた直線の傾きの $95 \%$ 信頼区 間から推定した Mnの誤差は約土50であった。

\subsection{GPC による測定}

前節までの $2 つ の$ 方法による分子量を, 従来の GPCによ る測定結果 (ポリスチレン換算分子量) と比較した。GPCに よる CLの分子量分布は 200 ～ 3000 程度（Fig. 8) で, Mn = 490 であった。ちなみに同様に測定したエイコサン $\left(\mathrm{C}_{20} \mathrm{H}_{42}\right.$, $\mathrm{Mn}=282)$, テトラデシルベンゼン $\left(\mathrm{C}_{20} \mathrm{H}_{34}, \mathrm{Mn}=274\right)$ は それぞれ 464, 356 となり, ポリスチレン換算分子量は実際

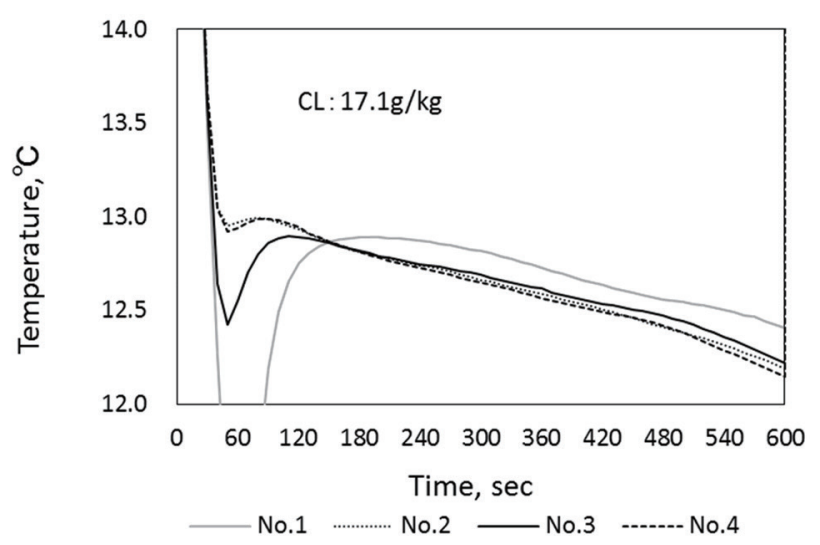

Fig. 6 Typical Cooling curves on the cryoscopy of $\mathrm{CL}$ 


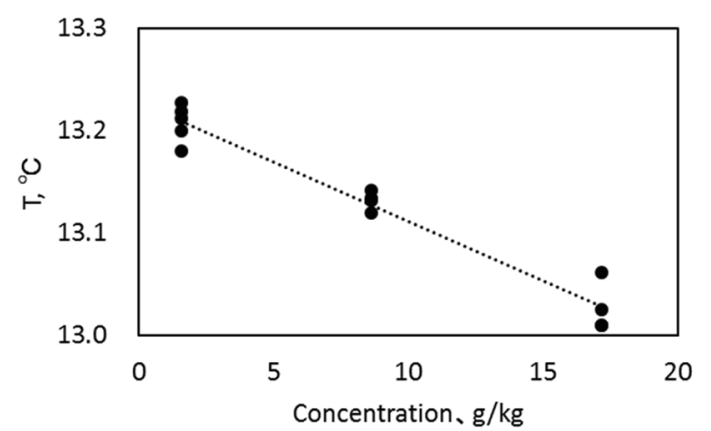

Fig. 7 Dependence of freezing point depression on the concentration of $\mathrm{CL}$

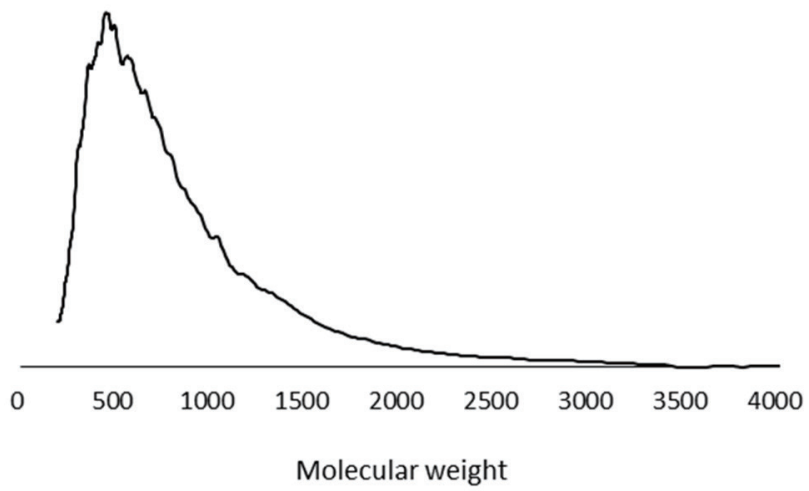

Fig. 8 Molecular distribution of CL by GPC

の分子量よりかなり大きく測定された。この結果，CLのよう な物質の分子量を GPCで測定する場合はポリスチレンに代 わる標準物質が必要なことが示された。これは今後の課題 であろう。

\section{4 測定法の比較}

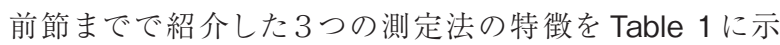
す。これらの方法のうち, 最も根拠のあるのは凝固点降下法 による值である。この方法は試料分子の形状, 極性依存し ないので, 物理化学的に最も意味のある方法である。しかし, 冷却曲線の再現性に由来する凝固点降下量に相当量の誤差 を含むこと, 約 $150 \mathrm{mg}$ の試料が必要であり測定に 4 時間以 上かかることから，参照試験としては有効であるがルーチン 分析には向かないであろう。

GCD を用いる場合は Fig. 4 に示す関係が分っていなくて はならない。アルカンは $\mathrm{C}_{60}$ まで常圧での沸点のデータがあ るが, アルキルベンゼンはノナデシルベンゼンまでしかない。 但し，アルキルベンゼンは炭素数 1 ～2 個多いアルカンと同 等の沸点を示すので, アルカンの変化を代用しても大きな相 違はない。CL の場合は $\mathrm{H} / \mathrm{C}$ 原子比はアルキルベンゼンより も若干大きいことから，アルキルベンゼンの較正曲線を用い て400 と推定した。このことから，飽和分のような， H/C 原 子比が概ね 1.7 以上で $\mathrm{N}, \mathrm{O}$ を含まない留分であれば GCD から分子量を推算することが可能であり，一定の条件で利用 価值の高い方法といえる。但し，この条件を満たす重質油 成分は飽和分のみである。SARA 分析による分画成分の芳 香族分は GCD に扔いて沸点と分子量の相関を得られるデー 夕が少ないこと,レジン分は飽和分に比べ沸点がかなり高く, GCD で解析可能なクロマトグラムが得られないことから, こ れらの留分については GCD 法の適用はできなかった。これ らについては更なる検討が必要である。

GPC による，ポリスチレン換算分子量は飽和分に対しては 過大評価することが示された。これはポリスチレンが $\mathrm{H} / \mathrm{C}$ 原子比 $=1.0$ であるのに対し, 飽和分は 1.7 以上と大きく異 なるのが理由の1つであろう。GPCを用いる場合は新たに標 準物質を選定する必要がある。

Table 1 Comparison of three molecular measurement methods

\begin{tabular}{|c|c|c|c|}
\hline & Cryoscopy & GCD (ASTM D7169) & $\mathrm{GPC}$ \\
\hline Determination method & Physicochemical principle & Calibration & Calibration \\
\hline Calibration standards & - & Alkanes/alkylbenzenes & Polystyrene \\
\hline Sample amount & $150 \sim 200 \mathrm{mg}$ & Less than $1 \mathrm{mg}$ & Less than $1 \mathrm{mg}$ \\
\hline Analysis time & More than $4 \mathrm{hrs}$. & $\begin{array}{c}\text { About } 40 \text { min } \\
\text { (except to obtain calibration curve) }\end{array}$ & $\begin{array}{c}\text { About } 40 \text { min } \\
\text { (except to obtain calibration curve) }\end{array}$ \\
\hline Measurement limitation & $\begin{array}{l}\text { Up to about MW } 500 \\
\text { p-Xylene soluble }\end{array}$ & $\begin{array}{l}\mathrm{FBP} \leqq \text { about } 700^{\circ} \mathrm{C} \\
\mathrm{H} / \mathrm{C} \text { atomic ratio }>1.7 \\
\text { Absence of nitrogen and oxygen } \\
\text { atoms }\end{array}$ & Tetrohydrofuran soluble \\
\hline Measuring error & About \pm 50 & $\begin{array}{c}\text { Depends on chromatographic } \\
\text { repeatability }\end{array}$ & $\begin{array}{l}\text { Depends on chromatographic } \\
\text { repeatability }\end{array}$ \\
\hline Results for CL fraction & $370 \pm 50$ & 400 & 490 \\
\hline
\end{tabular}

GCD: Gaschromatodraphic distillation

GPC: Gel-permeation chromatograpy

FBP : Final boiling point

CL fraction: Saturate fraction recovered from atmospheric residue of Cold Lake oilsand bitumen by almina-column chromatography (JPI$5 \mathrm{~S}-22-83)$ 


\section{4. 結 論}

重質油から分画した飽和分の分子量測定を GCD クロマ トグラムからの推算, 凝固点降下法および $\mathrm{GPC}$ の 3 通りの 方法で行った。 GCD は常圧換算沸点 $700^{\circ} \mathrm{C}$ 以下, $\mathrm{H} / \mathrm{C}$ 原子 比 1.7 以上の試料に利用可能であると推定された。重質油 の成分でこれに該当するのは，飽和分のみである。凝固点 降下法は分析精度の観点から分子量 500 以下に適用できる が，その場合，約 $150 \mathrm{mg}$ の試料が必要などの制約があった。 GPCではポリスチレン換算分子量では大きな誤差があった。

\section{文 献: References}

1) Hughey, C. A.; Rodgers, R. P.; Marshall, A. G., Anal. Chem., 74, 4145 (2002)

2) Miyabayashi, K.; Naito, Y.; Tsujimoto, K.; Miyake, M., Int. J. Mass Spectrom., 221, 93 (2002)

3) Tanaka, R.; Sato, S.; Takanohashi, T.; Hunt, J. E.; Winans, R. E., Energy Fuels, 18, 1405 (2004)

4) Shishido, T.; Cho, G.; Takanohasi, T.; Sato, S.; Saito, I., Prep. 35th Petroleum-Petrochemicals Symposium of JPI, 2A-21, p83, Oct. 27-28, 2005, Morioka, Japan : 宍戸貴洋, 張岩, 鷹觜利公, 佐藤信也, 斎藤郁夫, 第 35 回石油. 石油化学討論会講演要旨集, 2A-21, p83, 2005.10.27-28, 盛岡

5) Zhang, Y.; Shishido, T.; Takanohashi, T.; Sato, S.; Saito, I., Proc. Int. Conf. Coal Sci. Technol., 3P408 1, Oct. 9-13, 2005, Okinawa

6) Sato, S.; Takanohashi, T.; Tanaka, R., Prep. 12nd Annual Meeting of Jpn. Inst. Energy, 1-19, July 30-31, 2003, Sapporo, Japan：佐藤信也, 鷹觜利公, 田中隆三, 第 12 回日本エネルギー学会大会, 1-19, 2003.7.30-31, 札幌

7) Sato, S.; Takanohashi, T., Energy Fuels, 19, 1991 (2005)

8) Tanaka, R.; Sato, S., J. Jpn. Energy Inst., 80, 799 (2007)

9) Sato, S., Prep. 54th Conference on Coal Science, 2-11, Oct. 18-19, 2017, Akita, Japan：佐藤信也, 第 54 回石炭 科学会議, 2-11, 2017.10.18-19, 秋田

10） Sato, S., J. Jpn. Petrol. Inst., 59, 307 (2016)

11) Sato, S., J. Jpn. Petrol. Inst., 59, 311 (2016)

12) Chem. Soc. Jpn. ed., Handbook of Chemistry: Pure Chemistry, 5th ed., p II-142 (2004) : 日本化学会編, 改訂 5 版 化学便覧 基礎編, p II-142 (2004)

\section{Appendix GPC における式量と分子量の相関}

\section{1. はじめに}

参考文献に示した宍戸，張らの報告は口頭のみで行われ ており，その予稿の入手は困難である。そこで，その概要を 資料として以下に示す。但し, 張らが報告した式の変数は, 利用するためには更なる変換が必要なため, 筆者が理解し やすい変数に再変換した。

\section{2. 実験装置および試料}

GPC 分析は以下の条件で行った。 ポンプ：PU-980 (日本分光社)

検出器：UV-970, および RI-930（日本分光社）

カラム： Mixed-D × 2 本 (粒径 $5 \mu \mathrm{m}$, カラム内径 $7.5 \mathrm{~mm}$, 長さ $300 \mathrm{~mm}$, 排除限界 400000, Polymer Laboratories 社製)，

移動相：N-メチル - 2-ピロリジノン (NMP), テトラヒド ロフラン $(\mathrm{THF})$, クロロホルム $\left(\mathrm{CHCl}_{3}\right), 1 \mathrm{~mL} /$ $\min$

恒温槽：CO-965 (日本分光社), $40{ }^{\circ} \mathrm{C}\left(\mathrm{THF}, \mathrm{CHCl}_{3}\right)$, $60^{\circ} \mathrm{C}(\mathrm{NMP})$

注入量: $20 \sim 50 \mu \mathrm{L}$

検量線：ポリスチレン（分子量 102000, 49300, 5400, 870）拈よびジフェニルエタン（分子量 182）

分析試料には Table A1 に示す分子量 $200 \sim 1100$ の 59 種 類のモデル化合物を用いた。Table A1には後の計算で必要 となる $\mathrm{H} / \mathrm{C}$ 原子比, 分極率を併せて示した。各分子の構造 は CAS No. より調べることができる。

\section{3. 分子量補正のパラメータ}

分子量のずれが生じる原因としては物質の形状, 極性が 関係すると考え, 分子の性状と深い関係のある $\mathrm{H} / \mathrm{C}$ 原子比 の他, 分子容, 分極率, 双極子モーメントなどのパラメー夕 を選択し, 純物質の式量 (FW) とポリスチレン換算分子量 (MW) の相関を重回帰分析で検討した。なお, 分子容, 分 極率，双極子モーメントは分子モデリングソフト HyperChem 6.02 に備えられているQSARコマンドで計算した值を用いた。 その結果, 同一の溶媒に対する MW と FW の関係は H/ $\mathrm{C}$ 原子比と分極率で式 (A1)の形で整理できた。

$$
\mathrm{MWe}=\mathrm{A}+\mathrm{B} \cdot \mathrm{MW}+\mathrm{C} \cdot(\mathrm{H} / \mathrm{C})+\mathrm{D} \cdot \alpha
$$
ここで, MWe は式 (A1)による推算值, A, B , C, D は係 数, $\alpha$ は分極率を示す。各溶媒の係数を Table A2 に示す。 Table A2 の $\mathrm{R}^{2}$ 值は寄与率であり，いずれも 0.98 以上と高 い直線性を示した。ちなみに MW と H/C のみで回帰分析を 行うと, $\mathrm{NMP}, \mathrm{THF}, \mathrm{CHCl}_{3}$ の寄与率はそれぞれ 0.39, 0.86, 0.69 で，良い相関は得られなかった。Figs. A1〜A3にそれ ぞれの溶媒における FW に対する MW（○）および MWe （○）の分布を示す。いずれの場合も FW と MWe が良い一 致を示している。

\section{4. 溶媒の効果}

Table A2 の係数は溶媒により異なっている。そこで, 溶 媒の違いを数值化するために前節と同様の考え方で溶媒の パラメータを検索し, 溶媒効果の差を含む推算式を推定し た。その結果, 溶媒のパラメータとして分極率 $\left(\boldsymbol{\alpha}_{\mathrm{s}}\right)$ と双極 子モーメント $\left(\mathrm{p}_{\mathrm{s}}\right)$ の項を加えた式 (A2) で溶媒を含む相関 が1本の回帰式で表現できた。なお， NMP，THF， $\mathrm{CHCl}_{3}$ の分極率はそれぞれ 10.61，7.98，8.39 $\AA^{3}$, 双極子モーメ ントはそれぞれ，3.306，1.661，1.015 D である。 
Table A1 List of pre chemicals for GPC analysis

\begin{tabular}{|c|c|c|c|c|c|}
\hline $\begin{array}{c}\text { Formula } \\
\text { weight }\end{array}$ & Cas No. & Formula & $\mathrm{H} / \mathrm{C}$ & $\begin{array}{c}\text { Porarizability } \\
\AA^{3} \\
\end{array}$ & Compound \\
\hline 182 & $103-29-7$ & $\mathrm{C} 14 \mathrm{H} 14$ & 1.00 & 68.7 & 1,2-Diphenylethane \\
\hline 200 & 831-91-4 & $\mathrm{C} 13 \mathrm{H} 12 \mathrm{~S}$ & 0.92 & 72.5 & Benzyl phenyl sulfide \\
\hline 202 & 129-00-0 & $\mathrm{C} 16 \mathrm{H} 10$ & 0.63 & 75.2 & Pyrene \\
\hline 206 & $52251-71-5$ & $\mathrm{C} 16 \mathrm{H} 14$ & 0.88 & 76.2 & 2-Ethylanthracene \\
\hline 212 & $1207-15-4$ & $\mathrm{C} 14 \mathrm{H} 12 \mathrm{~S}$ & 0.86 & 74.5 & 2,8-Dimethyldibenzothiophene \\
\hline 216 & $1016-05-3$ & $\mathrm{C} 12 \mathrm{H} 8 \mathrm{O} 2 \mathrm{~S}$ & 0.67 & 66.8 & Dibenzothiophene sulfone \\
\hline 216 & $92-85-3$ & C12H8S2 & 0.67 & 74.8 & Thianthrene \\
\hline 218 & $5315-79-7$ & $\mathrm{C} 16 \mathrm{H} 10 \mathrm{O}$ & 0.63 & 76.8 & 1-Hydroxypyrene \\
\hline 228 & $92-24-0$ & $\mathrm{C} 18 \mathrm{H} 12$ & 0.67 & 85.6 & 2,3-Benzanthracene \\
\hline 228 & $1718-53-2$ & $\mathrm{C} 18 \mathrm{H} 12$ & 0.67 & 85.6 & 1,2-Benzanthracene \\
\hline 228 & $217-59-4$ & $\mathrm{C} 18 \mathrm{H} 12$ & 0.67 & 85.6 & Triphenylene \\
\hline 232 & $22463-15-8$ & $\mathrm{C} 17 \mathrm{H} 12 \mathrm{O}$ & 0.71 & 81.3 & 1-Pyrenemethanol \\
\hline 233 & $1148-79-4$ & C15H11N3 & 0.73 & 80.4 & $2,2^{\prime}: 6^{\prime}, 2^{\prime \prime}$-Terpyridine \\
\hline 243 & $2642-98-0$ & $\mathrm{C} 18 \mathrm{H} 13 \mathrm{~N}$ & 0.72 & 89.1 & 6-Aminochrysene \\
\hline 248 & $1081-34-1$ & $\mathrm{C} 12 \mathrm{H} 8 \mathrm{~S} 3$ & 0.67 & 81.2 & 2,2':5',2"-Terthiophene \\
\hline 252 & $198-55-0$ & $\mathrm{C} 20 \mathrm{H} 12$ & 0.60 & 93.4 & Perylene \\
\hline 254 & $604-53-5$ & $\mathrm{C} 20 \mathrm{H} 14$ & 0.70 & 95.9 & 1,1'-Binaphthyl \\
\hline 256 & 57-97-6 & C20H16 & 0.80 & 94.1 & 7,12-Dimethylbenz[a]anthracene \\
\hline 263 & 78902-09-7 & $\mathrm{C} 14 \mathrm{H} 17 \mathrm{NO} 4$ & 1.21 & 72.4 & Phthalimidoacetaldehyde diethyl acetal \\
\hline 266 & $63041-77-0$ & $\mathrm{C} 21 \mathrm{H} 14$ & 0.67 & 97.7 & 7-Methylbenzo[a]pyrene \\
\hline 276 & 191-24-2 & $\mathrm{C} 22 \mathrm{H} 12$ & 0.55 & 111.6 & Benzo[ghi]perylene \\
\hline 278 & $135-48-8$ & $\mathrm{C} 22 \mathrm{H} 14$ & 0.64 & 103.7 & Pentacene \\
\hline 278 & $53-70-3$ & $\mathrm{C} 22 \mathrm{H} 14$ & 0.64 & 103.7 & 1,2:5,6-Dibenzanthracene \\
\hline 278 & $215-58-7$ & C22H14 & 0.64 & 103.7 & 1,2:3,4-Dibenzanthracene \\
\hline 288 & $3443-45-9$ & $\mathrm{C} 20 \mathrm{H} 16 \mathrm{O} 2$ & 0.80 & 95.0 & 1-Pyrenebutylic acid \\
\hline 289 & $2131-18-2$ & $\mathrm{C} 21 \mathrm{H} 36$ & 1.71 & 99.7 & $n$-Pentadecylbenzene \\
\hline 294 & $6994-46-3$ & $\mathrm{C} 18 \mathrm{H} 18 \mathrm{~N} 2 \mathrm{O} 2$ & 1.00 & 93.9 & 1,4-Bis(ethylamino)-9,10-anthraquinone \\
\hline 300 & 191-07-1 & $\mathrm{C} 24 \mathrm{H} 12$ & 0.50 & 109.2 & Coronene \\
\hline 302 & $196-42-9$ & $\mathrm{C} 24 \mathrm{H} 14$ & 0.58 & 111.6 & Naphtho[2,3-a]pyrene \\
\hline 308 & $136453-59-3$ & $\mathrm{C} 22 \mathrm{H} 28 \mathrm{O}$ & 1.27 & 103.9 & 2,7-Di-tert-butylfluorenylmethanol \\
\hline 312 & $13138-48-2$ & $\mathrm{C} 22 \mathrm{H} 20 \mathrm{~N} 2$ & 0.91 & 111.5 & 3,3'-Dimethylnaphthidine \\
\hline 315 & 20303-31-5 & $\mathrm{C} 18 \mathrm{H} 21 \mathrm{NO} 4$ & 1.17 & 94.4 & Methyl 5-(benzyloxycarbonyl)-2,4-dimethyl-3-pyrrolepropinoate \\
\hline 317 & $14752-75-1$ & $\mathrm{C} 23 \mathrm{H} 40$ & 1.74 & 108.9 & $n$-Heptadecylbenzene \\
\hline 330 & 1499-10-1 & $\mathrm{C} 26 \mathrm{H} 18$ & 0.69 & 124.4 & 9,10-Diphenylanthracene \\
\hline 345 & 29136-19-4 & $\mathrm{C} 25 \mathrm{H} 44$ & 1.76 & 118.1 & $n$-Nonadecylbenzene \\
\hline 348 & $3236-71-3$ & C25H20N2 & 0.80 & 126.2 & 4,4'-(9-Fluorenylidene)dianiline \\
\hline 350 & $6994-46-3$ & $\mathrm{C} 22 \mathrm{H} 26 \mathrm{~N} 2 \mathrm{O} 2$ & 1.18 & 112.1 & 1,4-Bis(butylamino)-9,10-anthraquinone \\
\hline 350 & $3236-71-3$ & C25H18O2 & 0.72 & 122.3 & 4,4'-(9-Fluorenylidene)diphenol \\
\hline 354 & $15082-28-7$ & $\mathrm{C} 24 \mathrm{H} 22 \mathrm{~N} 2 \mathrm{O}$ & 0.92 & 119.6 & 2-(4-Biphenylyl)-5-(4-tert-butylphenyl)-1,3,4-oxadiazole \\
\hline 373 & $2083 / 9 / 2$ & C27H19NO & 0.70 & 133.0 & 2,5-Di(4-biphenylyl)oxazole \\
\hline 379 & $2646-15-3$ & C24H30N2O2 & 1.25 & 121.3 & 1,4-Bis(n-pentylamino)-anthraquinone (Oil Blue $\mathrm{N}$ ) \\
\hline 384 & $4430-15-3$ & C27H12O3 & 0.44 & 125.2 & Truxenone \\
\hline 385 & $114932-60-4$ & C24H19NO4 & 0.79 & 115.5 & 1-Pyrenebutyric acid N-hydroxysuccinimide ester \\
\hline 403 & $36395-57-0$ & $\mathrm{C} 28 \mathrm{H} 34 \mathrm{O} 2$ & 1.21 & 135.6 & a,a'-Bis(4-hydroxy-3,5-dimethylphenyl)-1,4-diisopropylbenzene \\
\hline 425 & $110726-28-8$ & C29H28O3 & 0.97 & 144.3 & a,a,a'-Tris(4-hydroxyphenyl)-1-ethyl-4-isopropylbenzene \\
\hline 431 & 7218-64-5 & $\mathrm{C} 26 \mathrm{H} 26 \mathrm{~N} 2 \mathrm{O} 2 \mathrm{~S}$ & 1.00 & 137.2 & 2,5-Bis(5-tert-butyl-2-benzoxazolyl)thiophene \\
\hline 439 & $117344-32-8$ & C29H26O4 & 0.90 & 144.5 & 4,4'-(9-Fluorenylidene)bis(2-phenoxyethanol) \\
\hline 451 & 191-48-0 & C36H18 & 0.50 & 163.8 & Decacyclene \\
\hline 533 & $517-51-1$ & $\mathrm{C} 42 \mathrm{H} 28$ & 0.67 & 178.8 & Rubrene \\
\hline 535 & $2683-82-1$ & C36H46N4 & 1.28 & 178.0 & 2,3,7,8,12,13,17,18-Octaethyl-21H,23H-porphine \\
\hline 599 & $76372-76-4$ & $\mathrm{C} 40 \mathrm{H} 26 \mathrm{~N} 2 \mathrm{O} 4$ & 0.65 & 191.0 & N,N'-Bis(2,6-dimethyloctyloxy)-3,4,9,10-perylenetetracarboxylic diimide \\
\hline 615 & 917-23-7 & C44H30N4 & 0.68 & 223.1 & 5,10,15,20-Tetraphenyl-21H,23H-porphine \\
\hline 619 & $16834-13-2$ & C40H26N8 & 0.65 & 218.9 & 5,10,15,20-Tetra(4-pyridyl)-21H,23H-porphine \\
\hline 629 & $56913-55-4$ & C36H40N2O8 & 1.11 & 187.5 & $\begin{array}{l}\text { Tetraethyyl 1,1'-(1,1'-biphenyl-4,4'-diyl)-bis-(2,5-dimethyl-1H-pyrrole-3,4- } \\
\text { dicarboxylate) }\end{array}$ \\
\hline 671 & $14527-51-6$ & C48H38N4 & 0.79 & 240.3 & 5,10,15,20-Tetra-p-tolyl-21H,23H-porphine \\
\hline 739 & 35984-93-1 & C48H50N8 & 1.04 & 236.5 & 2,9,16,23-Tetra-tert-butyl-29H,31H-phthalocyanine \\
\hline 767 & $83054-80-2$ & $\mathrm{C} 52 \mathrm{H} 50 \mathrm{~N} 2 \mathrm{O} 4$ & 0.96 & 245.5 & N,N'-Bis(2,5-di-tert-butylphenyl)-3,4,9,10-perylenedicarboximide \\
\hline 775 & $1709-70-2$ & C54H78O3 & 1.44 & 255.4 & 1,3,5-Trimethyl-2,4,6-tris(3,5-di-tert-butyl-4-hydroxybenzyl)benzene \\
\hline 939 & $58687-99-3$ & C64H58N8 & 0.91 & 309.3 & 2,11,20,29-Tetra-tert-butyl-2,3-naphthalocyanine \\
\hline 1091 & $116453-73-7$ & $\mathrm{C} 64 \mathrm{H} 82 \mathrm{~N} 8 \mathrm{O} 8$ & 1.28 & 326.8 & 1,4,8,11,15,18,22,25-Octabutoxy-29H,31H-phthalocyanine \\
\hline
\end{tabular}


Table A2 Coefficients for the parameter fitting equations 1 for three eluents

\begin{tabular}{cccccc}
\hline & $\mathrm{A}$ & $\mathrm{B}$ & $\mathrm{C}$ & $\mathrm{D}$ & $\mathrm{R}^{2}$ \\
\hline $\mathrm{NMP}$ & -46.48 & 0.0272 & 34.99 & 2.949 & 0.982 \\
$\mathrm{THF}$ & 3.49 & 0.1396 & -21.43 & 2.747 & 0.984 \\
$\mathrm{CHCl}_{3}$ & -5.81 & 0.1169 & -4.98 & 2.759 & 0.989 \\
\hline
\end{tabular}

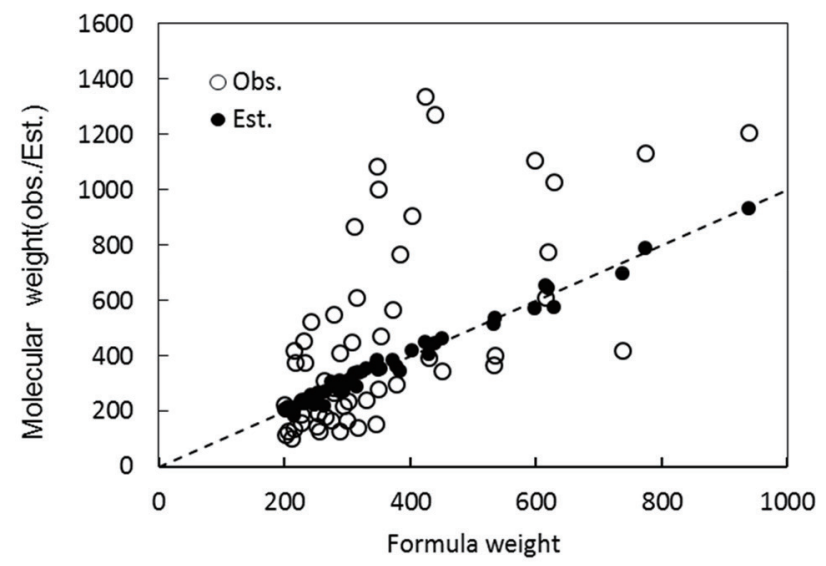

Fig. A1 Correlation between Formula weight and observed/ estimated molecular weights with NMP eluent

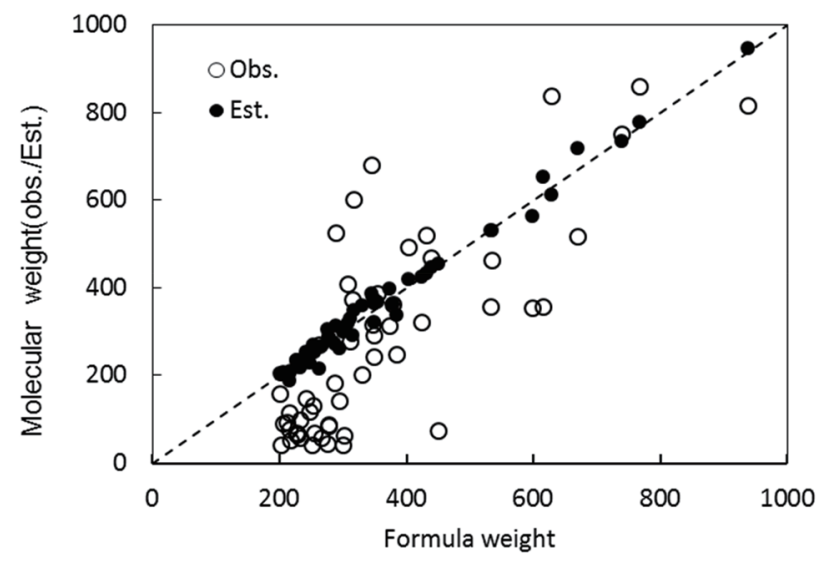

Fig. A2 Correlation between Formula weight and observed/ estimated molecular weights with THF eluent

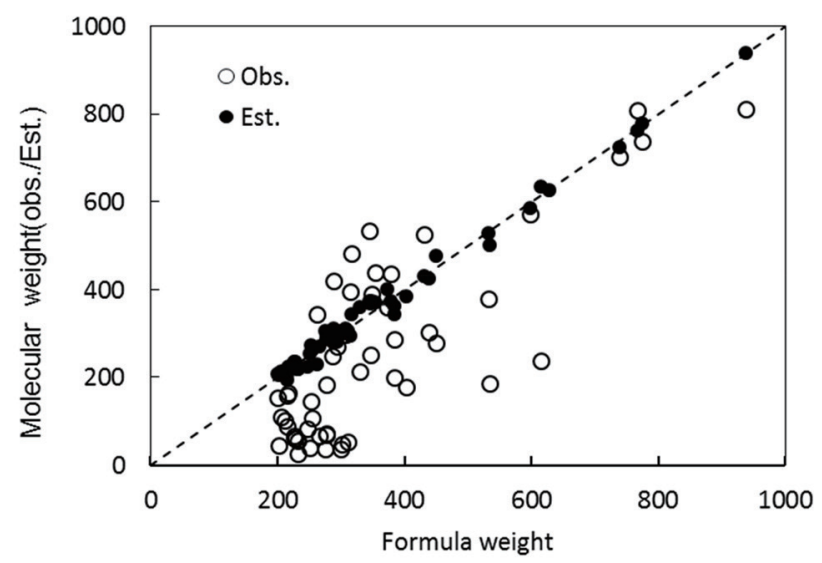

Fig. A3 Correlation between Formula weight and observed/ estimated molecular weights with $\mathrm{CHCl}_{3}$ eluent

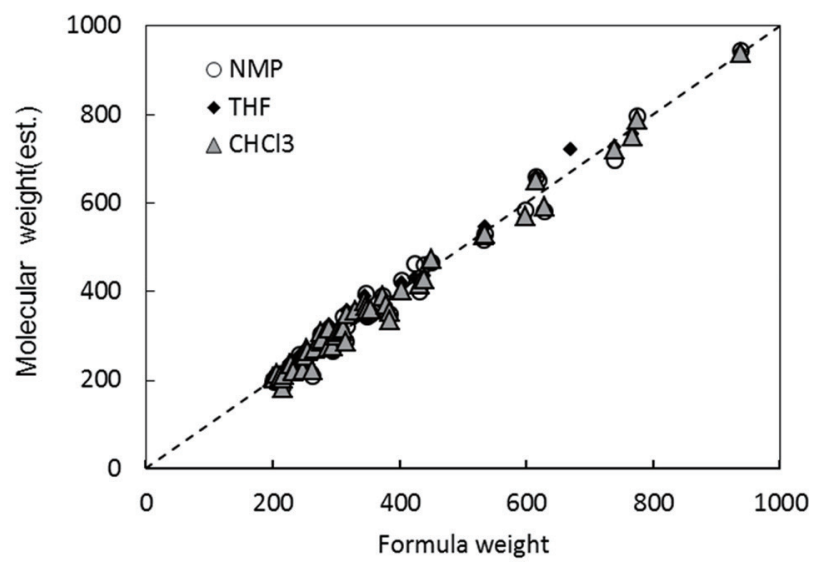

Fig. A4 Correlation between Formula weight and estimated molecular weights with NMP, THF and $\mathrm{CHCl}_{3}$ eluents

$$
\begin{aligned}
\mathrm{MWe}=\mathrm{A}^{\prime}+\mathrm{B}^{\prime} \cdot \mathrm{MW} & +\mathrm{C}^{\prime} \cdot(\mathrm{H} / \mathrm{C}) \\
& +\mathrm{D}^{\prime} \cdot \alpha+\mathrm{E} \cdot \alpha_{\mathrm{s}}+\mathrm{F} \cdot \mathrm{p}_{\mathrm{s}}
\end{aligned}
$$

ここで $\mathrm{A}^{\prime}, \mathrm{B}$, , C', D', E， F は係数であり，それぞれ， -10.670, 0.044，24.245，2.968，-2.997，-1.470であった。式 (A2)により推算した分子量は $\mathrm{FW}$ と寄与率 $\left(\mathrm{R}^{2}\right) 0.98$ 以上 で一致した（Fig. A4）。

\section{5. 推算式の意義}

宍戸，張らは式 (A1) および (A2)の係数の物理的意味に ついては議論していないが, 定性的に以下の効果が考えられ る。溶質の $\mathrm{H} / \mathrm{C}$ 原子比は分子の極性を示す。 $\mathrm{H} / \mathrm{C}$ 原子比 が大きいと極性が弱く，カラムとの相互作用が小さくなるた め保持時間が短くなり分子量が過大評価される。分極率は 溶質がカラムと接触したときの分極の起こりやすさ，すなわ ち，カラムとの相互作用の大きさを示す。これが大きいとカ ラムからの脱離が遅れ, 溶質の流出が遅くなり, 分子量が 過小評価される。

式 (A2) での溶媒の効果は, 溶媒の分極率が大きいと, 溶媒と溶質と間でカラムへの競争吸着が起こり, 溶質の流出 が早くなり，分子量が過大評価される。双極子モーメントは 溶媒と溶質の親和力を示すもので，この值が大きいとカラム からの脱離が早くなり, 結果として分子量が過大評価される。 推算式の係数の符号は, 概ねこれらの効果を相殺する方向 となっている。

上記の式は，既知の化合物が GPCで通常の解析をする と，どの程度の分子量を示すかを予測するには有効である。 しかし，未知の物質の保持時間から正しい分子量を予測す るためには $\mathrm{H} / \mathrm{C}$ 原子比や分極率のデー夕が必要で，そのた めには分子構造を推定することが必要で, そのためには分 子量が必要という矛盾がある。そのため, この知見は当面, GPCで得られた分子量を解釈する場合の基礎知識として用 いることが適当であろう。 